\title{
The Influence of ZnO NPs on Reproductive System Tissues of Albino Male Mice. Histopathological Study
}

\author{
Ruqayah Ali Salman \\ University of Al-Forat Al-Awsat Techniques
}

\begin{abstract}
Objective: To evaluate the influence of Zinc Oxide nanoparticles (ZnO NPs) on Albino male mice reproductive system. Methodology: Albino male mice were used in this study, divided to three groups (6 mice to each):control group, first treated $(150 \mathrm{mg} / \mathrm{kg} . \mathrm{bw}$.$) and second treated (350mg/kg.bw.). Result:After animal dissected, we tacked organs of reproductive system (testis,$ prostate, seminal vesicles and epididymis).The change in all tissues of reproductive system showed in (350mg/kg. bw.) dose treated with ZnO NPs, While the changes showed only in seminal vesicles and epididymis in the groups treated with (150mg/kg.bw.ZnONPs). Conclusion: The study established that a significant negative effect of ZnO NPs on Albino male mice reproductive tissues. Recommendation: Study the mechanism of ZnO NPs inside the body to know how can effects on body tissues.
\end{abstract}

Keywords: Zinc Oxide nanoparticles, reproductive system, male mice

\section{Introduction}

Spermatogenesis is a complex process proliferation and differentiationof germ cell which leads to the production and release of spermatozoa from the testis .This elaborate process dependent on hormonal and dynamic interactions between in the Sertoli cell and the germ cells[1,2].Many recent in vivo and in vitro studies identified that most nanoparticles (NPS) have a toxic effect on male germ cells $[3,4]$. Recent studies have shown that administration of NPS to mice result in their accumulation in the varioustissues including the brain and the testis .Thisconfirm that they easily pass through the blood -brain and blood testis barriers[5,6]. Not all NPS will necessarily demonstrate an adverse effect leading to toxicity for example. Some NPS shown a beneficial or nontoxic effect on spermatogenesis[7,8]. It has been reported that nano selenium diet supplementation produced positive effects on sperm quality in male goats[7]. Same timesnano particles can be beneficial or be damaging at the. Materials could be toxic and hazardous when they are converted into nano from[9].In ddition, the small size of nanoparticles allows them to overcome the defense barriers of the body without facing any obstacles[10]. ZnOnanoparticles have other applications besides the environmental usage, including rubber industry, glaze, cosmetics and medicine .Additionally, due to their antibacterial properties, ZnOnanoparticles can be used in preventive medicine against microbes associated with diseases and infections[11]. While Delouise, 2012[12], report, ZnOnanoparticles, have toxic effects on cultured dermal fibroblast cell. The present study aims investigate side effects of various doses $(150,350 \mathrm{mg} / \mathrm{kg})$ of $\mathrm{ZnO}$ NPs $(80 \mathrm{~nm})$ on reproductive system .

\section{Material and Method}

In this experimental study how examined 18 adult albino male mice in age 3 week (mean weight $=25+5 \mathrm{~g}$ ), purchased from the animal house of biotechnological center in Al-
Nahrai university . The animal divided to 3 groups ( 6 mice to each) allow free take pelleted and distal water under $23 \mp 2$ ${ }^{0} \mathrm{C}$ (With 12 hours light and 12 hours/darkness). Control group was taken water and food, and (first and secondtreated) group respectively reactivelyreceived doses $(150,350 \mathrm{mg} / \mathrm{kg})$ of ZnOnanoparticles prepared in distal water, after 15 days all animals was dissected, testis, prostate, seminal vesicles and epididymis tissues section was fixed in formalin solution, then embedded in paraffin, sectioned and stained with haematoxylin and eosin(H\&E) for histopathological study.

\section{Result}

The study showed the influence of $\mathrm{ZnO}$ NPs on reproductive system tissues in Albino male mice. The tissue sections in the first treated with $\mathrm{ZnO}$ NPs $(150 \mathrm{mg} / \mathrm{kg} . \mathrm{bw}$.) indicate several changes in the tissue of seminal vesicles and compare with control group,histopathological section of seminal vesicles showed focal hyperplasia of epithelial cells (figure 6). While don't show any changes in testicular tissues, prostate and epididymis tissues in the first treated compare with control group $(5,7,8,9)$. On the other hand, second treated with $\mathrm{ZnO}$ NPs $(350 \mathrm{mg} / \mathrm{kg} . \mathrm{bw})$ resulted incomplete spermatogenesis in certain seminiferous tubules, with vaculation of epithelial layer of testicular tissue (figure10,11), While the histological sections of theseminal vesicles showed tissue mild to moderate proliferation of epithelial cells, mononuclear cells infiltration in the stroma (figure 12,13). In addition to the observed changes in the tissue of the prostate by the occurrence pinkish homogenous material in dilated of their acini, hyperplasia of epithelial lining cells of their acini that from papillary projection into their lumen (figure 14,15,16). It is also observed epididymis sections that their ked fill with sperms (figure17,18). 


\section{International Journal of Science and Research (IJSR) \\ ISSN (Online): 2319-7064}

Index Copernicus Value (2015): 78.96 | Impact Factor (2015): 6.391

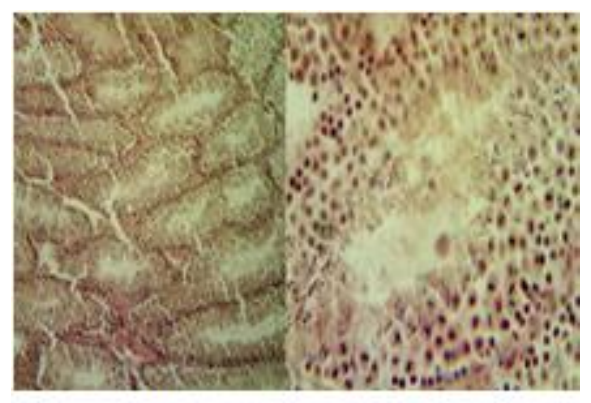

a

b

Figure1:Histopathological section in the testis showed normal structures, H \&E stain.(a100X, b 400X). (control group)

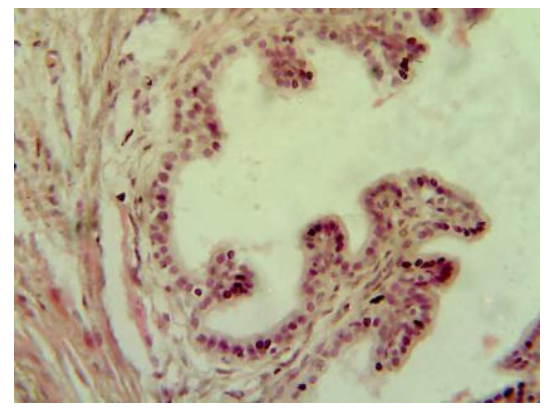

Figure 2:Histopathologica section in the seminal vesiclesshowed normal structures, $\mathrm{H} \& \mathrm{E}$ stain.(100X)(control group)

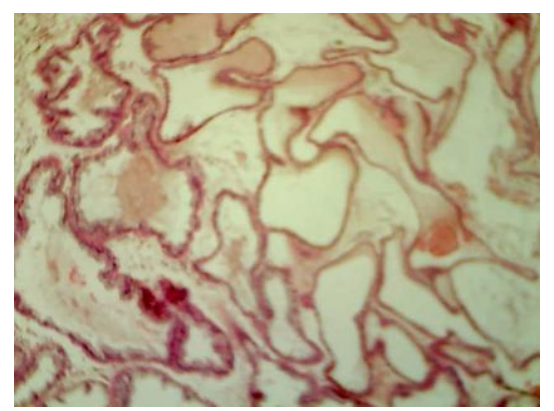

Figure 3:Histopathologica section in the prostatshowednormal structures,H \&E stain.(100X)(control group)

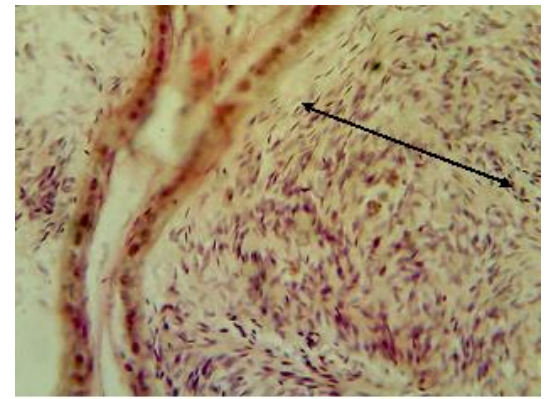

Figure 4:Histopathological section in the epididymis showed normal structures, H \&E stain.(400X).(control group)

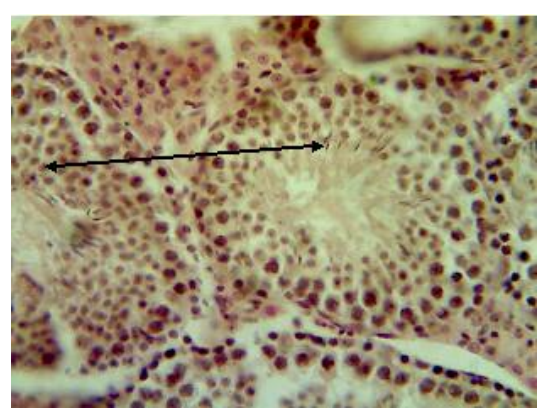

Figure 5: Histopathological section in the testis showed complete spermatogenesis with sperm in thelumin of seminiferous tubules (H \&E stain 400X). (first treated)

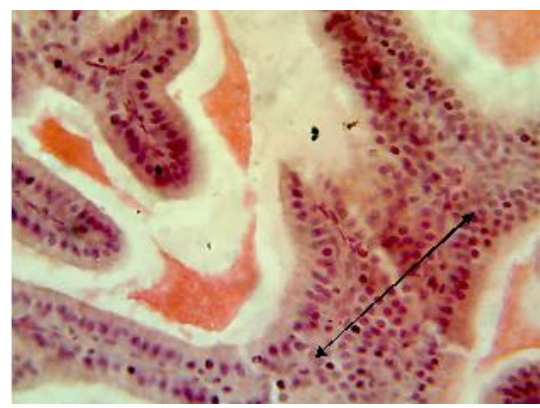

Figure 6: Histopathological section in the seminal vesicles showed focal hyperplasia of epithelial cells, $\mathrm{H} \& \mathrm{E}$ stain (400X). (first treated)

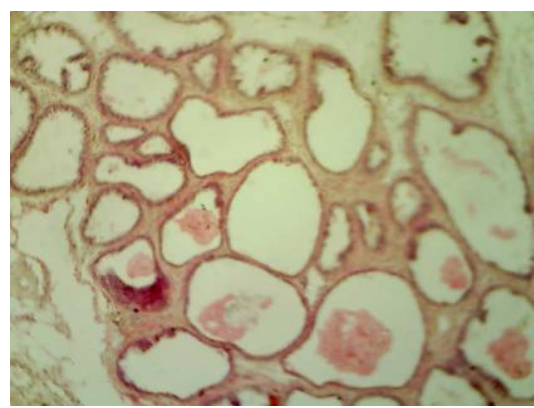

Figure 7: Histopathological section in the prostat showed normal structure $\mathrm{H} \& \mathrm{E}$ stain (400X).(first treated)

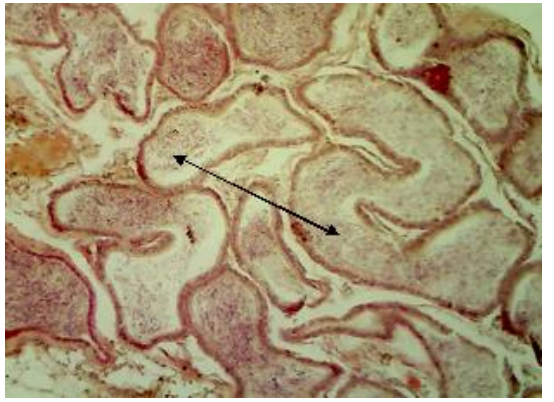

Figure 8: Histopathological section in the epididymis showed their tubules filled with sperms, $\mathrm{H} \& \mathrm{E}$ stain.(100X)(first treated) 


\section{International Journal of Science and Research (IJSR) \\ ISSN (Online): 2319-7064}

Index Copernicus Value (2015): 78.96 | Impact Factor (2015): 6.391

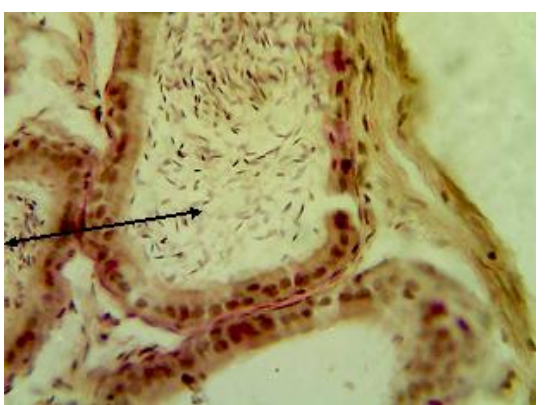

Figure 9:Histopathological section in the epididymis showed their tubules filled with sperms, H \&E stain.(400X)(first treated)

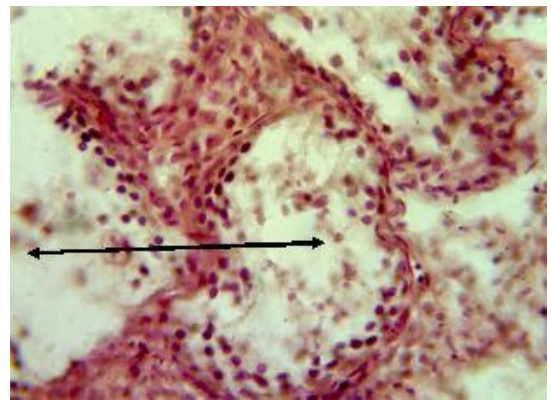

Figure 10: Histopathological section in the testis showed incomplete spermatogenesis in certain seminiferous tubules, $\mathrm{H} \& \mathrm{E}$ stain.(400X)(second treated)

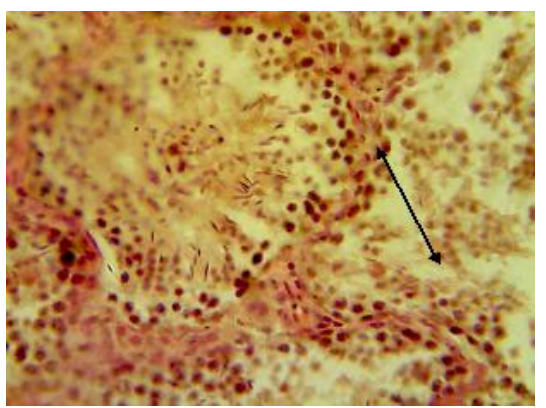

Figure 11: Histopathologica section in the testis showed that certain seminiferous tubules expressed incomplete spermatogenesis with vacuolation of epithelial layer, $\mathrm{H}$ \& E stain. $(400 \mathrm{X})($ second treated)

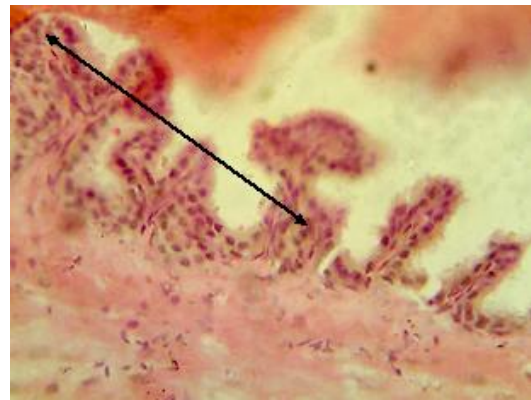

Figure 12: Histopathologicla section in the seminal vesicles showed mild to moderate proliferation of epithelial cells, $\mathrm{H} \& \mathrm{E}$ stain. $(400 \mathrm{X})$ ( second treated)

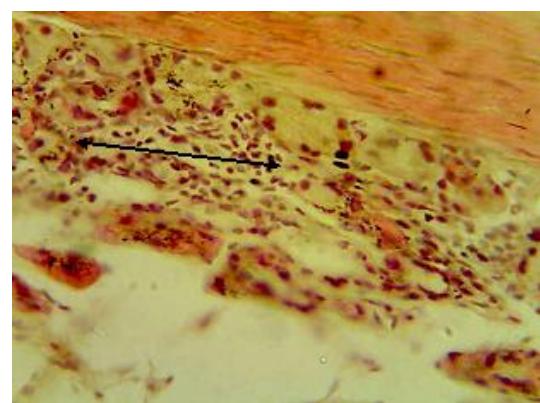

Figure 13: Histopathologicla section in the seminal vesicles showed mononuclear cells infiltration in the stroma, $\mathrm{H}$ \& E stain. $(400 \mathrm{X})$ ( second treated)

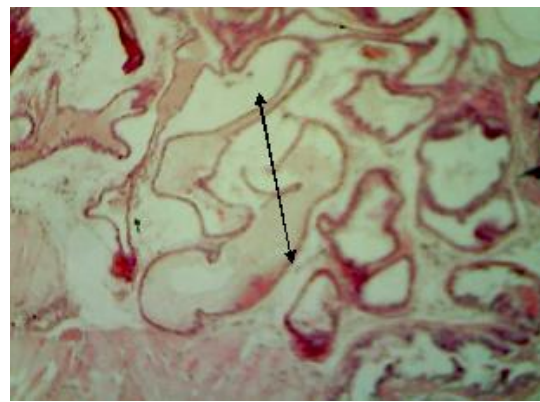

Figure 14: Histopathological section in the prostat showed dilated of their acini, $\mathrm{H} \& \mathrm{E}$ stain.(100X)( second treated)

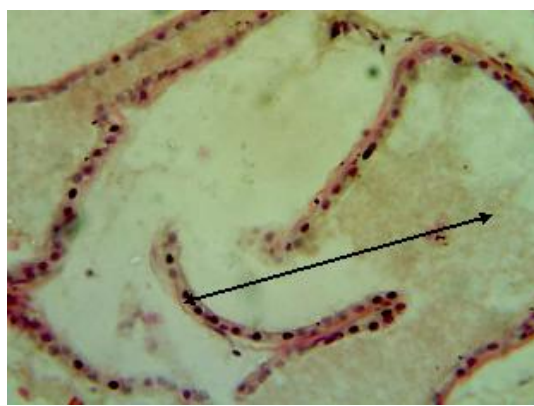

Figure 15: Histopathological section in the prostat showed pinkish homogenous material in dilated of their acini, $\mathrm{H}$ \&E stain. $(400 \mathrm{X})$ ( second treated)

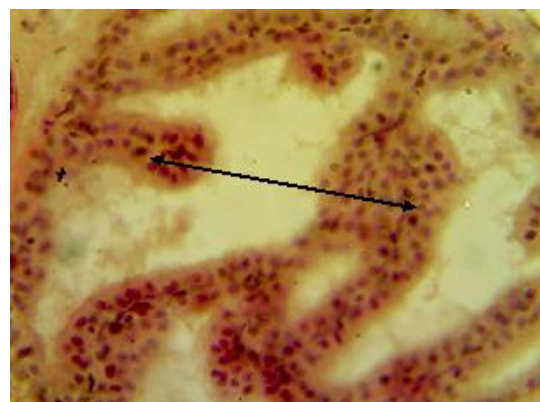

Figure 16: Histopathological section in the prostat showed hyperplasia of epithelial lining cells of their acini that form papillary projection into their lumen,H\& E stain. (400X)( second treated) 


\section{International Journal of Science and Research (IJSR) \\ ISSN (Online): 2319-7064}

Index Copernicus Value (2015): 78.96 | Impact Factor (2015): 6.391

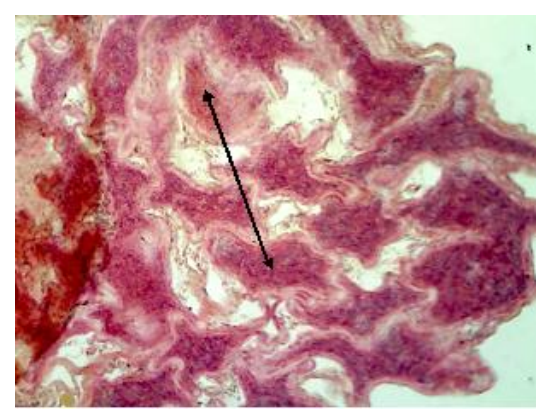

Figure 17: Histopathologicla section in the rete epididym showed sperms fill their lumen, H \&E stain.(400X) (second treated)

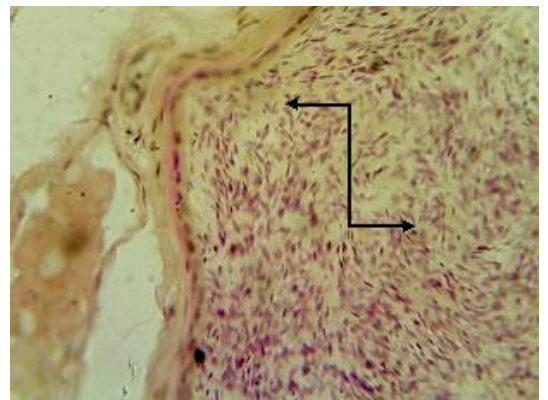

Figure 18: Histopathological section in the epididymis showed their ked fill with sperms, H \& E stain. $(400 X)($ second treated)

\section{Discussion}

Apgar J., 1992[13],showed the metals like Zinc(Zn), gold $(\mathrm{Au})$ and nickel $(\mathrm{Ni})$ play a significant role in male reproductive functioning and deficiency of these trace metals have negative impact on spermatogenesis and semen quality . Hajar S. et al., 2014 [14] demonstrated that the influence of $\mathrm{ZnO}$ NPs on testiculartissues by sloughing of cell layers (stare) and impairment in the production of spermatogenesis in seminiferous tubules. ZnO NPs in our study,through their impact on Sertolicells and occurrence of vacuolation phenomenon and the following apoptosis, have caused reduction in various cell lines including spermatogonia, round and elongated spermatids [14]. Also impact of $\mathrm{ZnO}$ NPs on reproductive organs in female animals [15]. It can be inferred that ZnO NPs are associated with oxidative stress (ROS), which result in an increase in DNA double-strand breakage and a decrease in sperm motility, ROS may penetrate across the cell membrane and inhibit the activity of some vital enzymes such as glucose 6phosphatase dehydrogenase G6PDH. The ROS may also lead to mutations such as point mutations and polymorphism and thus reduce semen quality. This study agree with Yoshida M, et al., 2012[16], who studied the effect of NPs reduction is related to lyedig cell degeneration and the damage to the seminiferous tubules.As Talebiet AR, et al. 2013,[17] reported, regarding epididymis sperm characteristics including mobility, the percentage of normal cells compared to abnormal ones.

According to their study, low dose $(150 \mathrm{mg} / \mathrm{kg}$ bw.) administration of $\mathrm{ZnO}$ NPs don't show changes in tissue of testis and prostate gland. While the changes found in seminal vesicles. These effects were less significant compared to the dose of $350 \mathrm{mg} / \mathrm{kg}$ bw. Concentration and exposure mode have an important role in the toxicity of $\mathrm{ZnO}$ NPs [18].

\section{Conclusion}

This study has established that Zno NPS has cytotoxic on testicular tissue in a dose dependent manner. But in general, $\mathrm{ZnO}$ NPS showed significant negative effects on albino mal mice reproductive system.

\section{Recommendation}

1) More study need to know the mechanism by which $\mathrm{ZnO}$ NPs exerts it's effects.

2) Study along time exposure to $\mathrm{ZnO} \mathrm{NPs}$, to know the impact of NPs on fertility in males.

3) Take different dose levels from $\mathrm{ZnO}$ NPs.

\section{References}

[1] Franca LR; Ghosh S; Ye SJ and Russell LD. (1993). Surface and surface to volume relationships of the Sertoli cells during the cycle of the seminiferous epithelium in the rat. Biol. Reprod., 49 (6):1215-28.

[2] Boekelheide K; Fleming SL; Johnson KJ; Patel, SR and Schoenfeld HA. (2000). Role of Sertoli cells in injuryassociated testicular germ cell apoptosis. Exp. Biol. Med., 225(2): 105-15.

[3] Braydich-Stolle LK; Lucas B; Schrand A; Murdock RC; Lee $\mathrm{T}$ and Schlarger JJ. (2010). Silver nanoparticles disrupt GDNF/Fyn kinase signaling in spermatogonial stem cells. Tpoxicol. Sci., 116 (2): 577-89.

[4] Braydich-Stolle L; Hussain S.; Schlager JJ and Hofmann MC. (2005). In vitro cytotoxicity of nanoparticles in mammalian germline stem cells. Toxicol. Sci., 88(2): 412-9.

[5] Borm PJ and Kreyling W. (2004). Toxicological hazards of inhaled nanoparticles potential implications for drug delivery. J. Nanosci. Nanotechnol., 4(5): 52131.

[6] Chen Y; Xue Z.; Zheng D.; Xia K.; Zhao Y. and Liu T. (2003). Sodium chloride modified silica nanoparticles as a non-viral vector with a high efficiency of DNA transfer into cells. Curr. Gene Ther., 3 (3): 273-9.

[7] Shi L. and Xue W. (2011). Effect of sodium selenite, Se-yeast and nano-elemental selenium on growth performance, Se concentration and antioxidant status in growing male goats. Small Ruminant Res., 96(1): 4952.

[8] Shi L.; Yang R.; Yue W.; Xun WJ.; Zhang CX. And Ren YS. (2010). Effect of elemental nano-selenium quality, glutathione peroxidase activity, and testis ultrastructure in male Boer goats. AnimReprod. Sci., 118 (2-4): 248-54.

[9] Fiorito S.; Serafino A.; Andreola F. and Bernier P. (2006). Effects of fullerenes and single-wall carbon nanotubes on murine and human macrophages. Carbon., 44(6): 1100-1105.

[10]Reddy LS.; Nisha MM,; Joice M. and Shilpa PN. (2014). "Antimicrobial activity of zinc oxide $(\mathrm{ZnO})$ nanoparticle againstklebsiella pneumonia". Pharm. Biol., 15: 1.

\section{Volume 6 Issue 7, July 2017 www.ijsr.net}




\section{International Journal of Science and Research (IJSR) \\ ISSN (Online): 2319-7064}

Index Copernicus Value (2015): 78.96 | Impact Factor (2015): 6.391

[11] Nadafi K.; Zare M.; Ali Mohammad BM.; Rastkari N. and Rastkari N. and Mousavi N.(2011). Evaluation of the toxicity of $\mathrm{ZnO}$ nanoparticles and titanium oxide by biological tests using Escherichia coli bacteria ATCC35218 and staphylococcus aureus ATCC25923, Health and Environment magazine. 2: 171-180.

[12] Delouise LA, 2012. Applications of nanotechnology in dermatology. J. InvestigDermatol. 132(3p12): 964-75.

[13] Apgar J. (1992). Zinc and reproduction: An update. J. Nutr. Biochem., 3: 266-78.

[14]Hajar S.; Ali N. and Amir MasoudMashayekh (2014). The effect of $\mathrm{ZnO}$ nanoparticles on the grouth and puberty of newborn male wistar rats. International J. Basic Sci. Applied Research, 3(sp): 180-185.

[15] Esmaeillou M; Moharamnejad M. and Hsankhani R. (2013). Toxicity of $\mathrm{ZnO}$ nanoparticles in healthy adult mice. Environmental toxicology and pharmacology, 35: 67-71.

[16] Yoshida M.; Yoshida S.; Sugawara L. and Takeda K. (2002). Matemal exposure to diesel exhaust decrease expression of steroidognic factor-1 and mulevian inhibiting of substance in the murine fetus. J. Heal. Sci., 48: 317-24.

[17] Talebi AR; Khorsandi L. and Moridian M. (2013). The effect of Zinc oxide nanoparticles on mouse spermatogenesis. J. Assist. Reprod. Genet., 30(9): 12039.

[18] Adamcakova, DA.; Stebounova LV.; Sung KJ.; Vorrink SU.; Ault AP.; OShaughnessy PT.; Grassian, VH. And Thorne, PS. (2014). Toxicity assessment of zinc oxide nanoparticles using sub-acute and sub-chronic murine inhalation models. Particle Fiber Toxicol., 11:1-15.

Volume 6 Issue 7, July 2017 www.ijsr.net 